\title{
IMAGING OF SPLENIC HAMARTOMA
}

\section{Goher A. ', Milyushina Ya.A. ${ }^{2}$}

plenic hamartoma is a benign vascular proliferative lesion. It is generally found 1 - Dubai Hospital. incidentally during imaging tests performed for other reasons or at autopsy. Most Radiology department of commonly splenic hamartoma is a solitary or multiple, round, well-circumscribed, diagnostic imaging. unencapsulated, and dark red nodule compressing the adjacent normal parenchyma. Splen- Dubai, UAE. ic hamartoma usually remains asymptomatic, but the presence of the clinical symptoms oc- 2 - Semey State Medical curs from mass effect if they grow larger. The most important issue is a differential diagno- University. sis between benign and malignant mass. We report a case splenic hamartoma imaging, Semey, which was revealed at male patient of 40 years old. Republic of Kazakhstan.

Keywords: spleen, hamartoma, benign tumor, imaging.

Corresponding author: Goher A., e-mail: alimgoher@gmail.com

For citation: Goher A, Milyushina Ya. A. Imaging of splenic hamartoma: a case report. REJR 2018; 8 (2):239-241. DOI:10.21569/2222-7415-2018-8-2-239-241.

Received: 01.04.2018 Accepted: 18.05.2018

\section{АУЧЕВАЯ АИАГНОСТИКА ГАМАРТОМЫ СЕАЕЗЕНКИ}

\author{
Гохер А. ', Ми^юшина Я.А. ${ }^{2}$
}

$\Gamma$

амартома селезенки - доброкачественная сосудистая опухоль. Она обычно выявляется случайно во время диагностических исследований, выполненных по другим причинам, или при вскрытии. Чаще всего гамартома селезенки представляет собой одиночный или множественный округлый, хорошо очерченный, неинкапсулированный темно-красный узел, оказывающий давление на соседнюю нормальную паренхиму. Обычно гамартома селезенки бессимптомна, появление клинических симптомов связано с ростом опухоли.

Цель исследования. Представить актуальность и возможности применения ультразвукового метода исследования в диагностике гамартомы селезёнки.

Материалы и методы. Представцен случай гамартомы селезенки, выявменный у мужчины 40 мет.

Выводы. Важнейшим вопросом является дифференциальный диагноз между доброкачественной и змокачественной природой выявленной опухоли. Представленный кАинический случай демонстрирует актуальность применения и диагностические возможности ультразвукового исследования при данной патологии.

К^ючевые слова: селезенка, гамартома, доброкачественная опухоль, визуальная диагностика.

Контактный автор: Гохер А., e-mail: alimgoher@gmail.com

Для иитирования: Гохер А., Милюшина Я.А. Аучевая диагностика гамартомы селезенки: случай из практики. REJR 2018; 8 (2):239-241. DOI:10.21569/2222-74152018-8-2-239-241.

Статья получена: $\quad$ 01.04.2018 $\quad$ Статья принята: $\quad$ 18.05.2018 
plenic hamartoma is a very rare benign tumor, which is usually found incidentally after splenectomy, diagnostic imaging or autopsy $[1,2]$. It was firstly described in 1861 by Rokitansky [3, 4]. Since 1861, 170 to 190 cases have been reported in the literature [5]. Hamartomas are also known as a spleen within a spleen, post-traumatic scars, nodular hyperplasia, and hyperplastic nodules [1,2]. Although most of the reports in the literature consist of adult patients of an average age of 40-50 years, some of the reports indicate that $20 \%$ of hamartomas occur in children. No reliable data exist on the incidence of splenic hamartoma. In autopsy studies, an incidence of $0.024-0.13 \%$ has been reported, while an incidence of $0.015 \%-2.7 \%$ was noted among the patients that had undergone a splenectomy [5]. They seem to occur equally in male and female patients, but women seem to have larger lesions, probably due to hormonal influence [6]. Hamartomas of the spleen have been associated with hematologic disorders, tuberous sclerosis, malignant neoplasms, and Wiskott-Aldrich-like syndrome $[1,2]$. Here, we report a case of splenic hamartoma, which was incidentally discovered.

Case History.

A 40-year-old Arabic male presented with history of pain in right hypochondria. Ultrasonogram examination was done to exclude gall bladder calculi. The gall bladder was intact, but it was incidentally discovered iso- to slight hyperechoic mass in spleen [Fig. 1]. Then CT was done for better assessment.

CT showed large isodense mass of $7 \times 8 \times 7$ $\mathrm{cm}$ in sizes inseparable from the spleen, display-

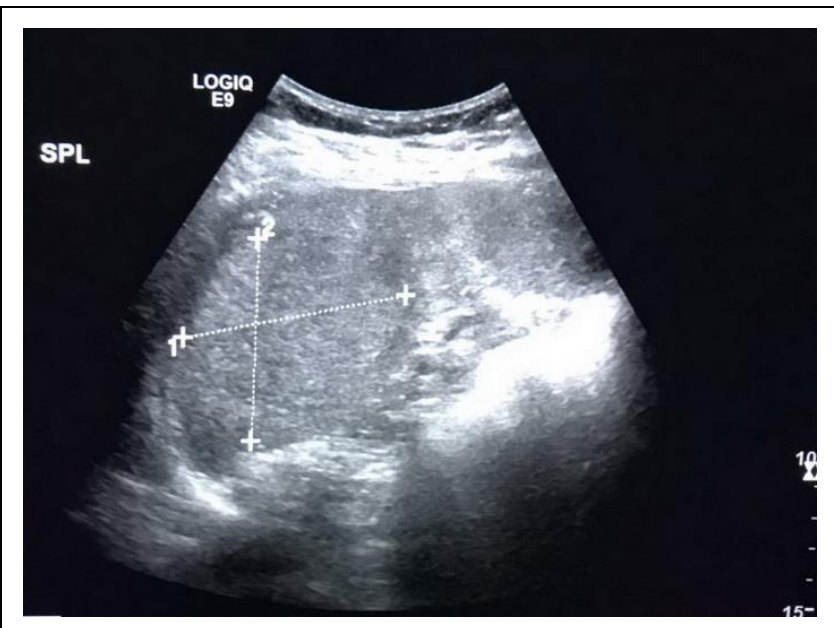

Fig. 1. Ultrasound.

It shows iso- to hyperechoic mass of the spleen $6.5 \times 7.0 \times 7.5 \mathrm{~cm}$ in dimensions.

Рис. 1. Узи.

Изо-, гиперэхогенная масса в селезенке размером 6.5 × 7.0 × 7.5 см. ing isodensity at plain $\mathrm{CT}$, relative hypodense to spleen at arterial phase and becoming isodense to spleen at venous and delayed phases [Figure 2]. The lesion is splenic in origin denoted by the presence of claw sign with splenic parenchyma and its pattern of enhancement. No calcification was revealed. Regional mass effect is noted in the form of mild compression of the splenic parenchyma, mild ptosis of the left kidney and mild displacement of the splenic vessels. No enlarged lymph nodes. Normal appearance of both suprarenal glands with no focal or diffuse abnormalities. Small focal lesion measuring about $22 \times 11 \mathrm{~mm}$ in diameter was seen at segment $\mathrm{V}$ of the liver displaying characteristic enhanced pattern of haemangioma. Normal appearance of the pancreas and both kidneys apart from bilateral tiny renal cortical cysts.

Further an ultrasonographic guided biopsy was carried out and histopathologic examination confirmed diagnosis of splenic hamartoma.

\section{Discussion.}

The pathogenesis of splenic hamartoma is controversial. Some consider hamartoma as the congenital malformation of the red pulp, excessive and disorganized growth of abnormally formed red pulp, a neoplasm, or a reactive lesion to prior trauma [7]. Hamartomas present as solitary or multiple lesions forming round, wellcircumscribed, unencapsulated bulging nodules compressing the adjacent normal splenic parenchyma. The tumors vary in size with a median size

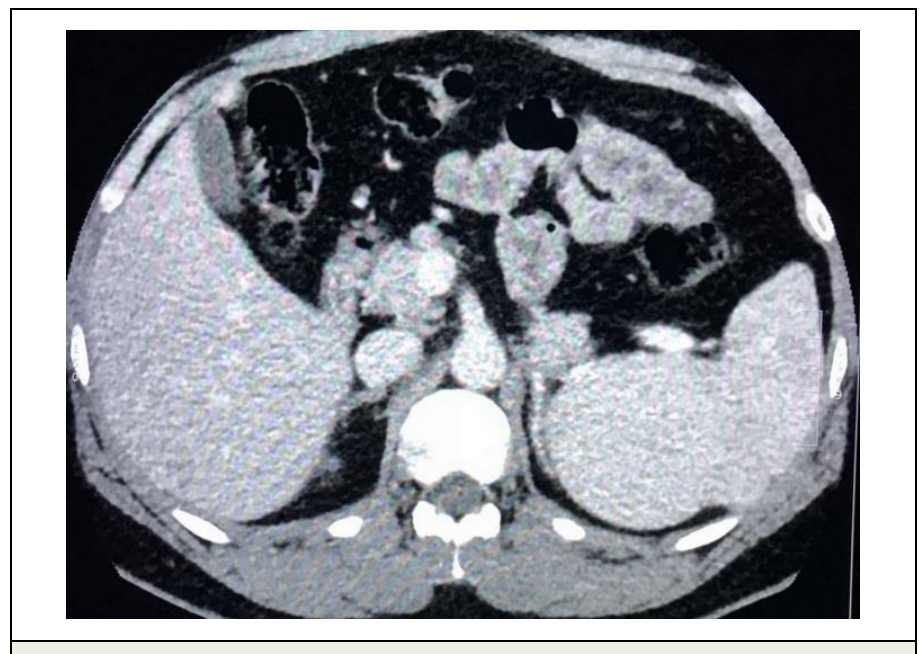

Fig. 2. Computed tomography imaging (axial plane, venous phase).

The homogeneous enhancing splenic mass equal to splenic parenchyma $7.0 \times 8.0 \times 7.0 \mathrm{~cm}$ in dimensions

\section{Рис. 2. Компьютерная томография (аксиаль- ная проекция, венозная фаза).}

Гомогенное объемное образование селезенки повышенной плотности, равной плотности паренхимы селезенки, размером $7.0 \times 8.0 \times 7.0 \mathrm{~cm}$. 
of $5 \mathrm{~cm}$ and a maximum of $20 \mathrm{~cm} \mathrm{[1,3,8].} \mathrm{There}$ are two types of splenic hamartoma: the pulposal type, resembling the splenic red pulp, and the lymphoid type, resembling the splenic white pulp [9]. Most tumors are a mixture of the two subtypes [8]. Histologic findings of hamartoma reveal disorganized vascular channels lined by slightly plump endothelial cells without atypia, mixed with intervening splenic red pulp-like stroma with or without white pulp [3, 4]. Splenomas are usually asymptomatic and discovered incidentally in adult patients at imaging studies performed for other reasons or at autopsy; however, in literature there are also some documented cases of symptomatic hamartomas in children, associated with hematologic disorders, such as pancytopenia, anemia, and thrombocytopenia [4]. A large hamartoma may be manifested as a palpable mass or splenomegaly. Rupture of a splenic hamartoma is rare [2]. Approximately $20 \%$ of the patients are presented with non-specific symptoms. The main complaints of these patients are abdominal pain and digestion problems [1, 3, 10]. Most splenic hamartomas are hyperechoic masses on sonography, with or without cystic changes. Although imaging features of splenic hamartoma can be nonspecific, hamartomas usually appear on CT as homogeneous iso-hypodense solid ball-like masses on non-enhanced scans, with progressive heterogeneous contrast enhancement, relatively to adjacent normal splenic parenchyma, after contrast agent injection [4]. It is important to differentiate hamartoma from splenic malignancies, including metastatic tumors [8]. Although the popularity of modern radiologic imaging techniques, such as ultrasound, color Doppler ultrasound, computed tomography, and MRI, make it possible

\section{References:}

1. Wang J.H., Ma X.L., Ren F.Y., Zuo C.J., Tian J.M., Wang Z.F., et al. Multimodality imaging findings of splenic hamartoma: A report of nine cases and review of the literature. Abdom Imaging. 2013; 38: 154-162.

2. Vos P.M., Bernard S.A., Cooperberg P.L. Benign and malignant lesions of the spleen. In: Gore R.M., Levine M.S., editors. Textbook of Gastrointestinal Radiology. 4th ed. Philadelphia: Elsevier-Saunders; 2015. 1923-1964 p.

3. Lee H., Maeda K. Hamartoma of the Spleen. Arch Pathol Lab Med. 2009; 133: 147-151.

4. Giambelluca D., Picone D., Re G.L., Pappalardo S., Romeo P. Hamartoma of the spleen (splenoma) with calcifications in a child with beta-thalassemia: A case report. J Radiol Case Rep. 2017; 11: 7-12.

5. Yazici P., Aydin U., Ersin S., Kaplan H. Hamartoma - a rare benign tumor of the spleen: a report of four cases. Eurasian $J$ Med. 2008; 40: 48-51. for early detection of the splenic hamartoma, definitive diagnosis depends on tissue examination [7]. An exact preoperative diagnosis is rarely established. Because the malignant counterpart of splenic hamartoma and splenic hemangioma are virtually identical, as well as the inflammatory pseudotumor and follicular dendritic cell sarcoma, the diagnosis must be confirmed by histopathological findings [5].

In our case we described the splenic hamartoma which was incidentally found at patient with complains of pain in right hypochondria in ultrasonographic examination. On sonography it looked as homogeneous mass of iso- to slight hypoechoic appearance, then $\mathrm{CT}$ examination for diagnosis specification was carried out. We considered a providing a following MRI examination is non-informative, so definitive diagnosis was confirmed histopathologically by percutaneous US guided biopsy.

\section{Conclusion.}

However, recent progress in imaging diagnostics has helped us to detect splenic tumor, the most important issue is a differential diagnosis between benign and malignant mass. If splenic hamartoma is supported by radiological findings and clinical evaluation, an elective splenectomy or percutaneous biopsy should be performed to make a definitive diagnosis by histological examination.

\section{Источник финансирования и кон- фиикт интересов.}

Авторы данной статьи подтвердими отсутствие финансовой поддержки исследования и конфцикта интересов, о которых необходимо сообщить.

6. Vlachou P., Fagkrezos D., Tzivelopoulou A., Kyriakopoulou G., Maniatis P., Triantopoulou C., et al. A rare case of a splenic hamartoma in a patient with a huge palpable abdominal mass: a case report. J Med Case Rep. 2015; 9: 4.

7. Cheng N., Chen J., Pan Y., Jiang Y., Zhou J., Shao C. Splenic hamartoma with bizarre stromal cells: a case report and literature review. Diagn Pathol. 2018; 13: 8.

8. Sim J., Ahn H.I., Han H., Jun Y.J., Rehman A., Jang S.M., et al. Splenic hamartoma: A case report and review of the literature. World J Clin Cases. 2013; 1: 217-9.

9. Komo T., Hihara J., Kanou M., Kohashi T., Ohmori I., Yoshimitsu M., et al. Splenic hamartoma associated with thrombocytopenia: A case report. Int J Surg Case Rep. 2017; 39: 172175.

10. Eker T., Kocaay A.F., Sevim Y., Çakmak A. Splenic hamartoma is a rare cause of abdominal pain: Case report and literature review. Turk J Surg. 2015; 33: 294-295. 